\title{
How Sustainable Enterprises Can Drive The Sustainable Development
}

\author{
Patrizia Gazzola, (Associated Professor, PhD) \\ University of Insubria, Italy \\ Eka Sepashvili, (Associated Professor, PhD.) \\ Tbilisi State University, Country \\ Roberta Pezzetti, (Associated Professor, PhD.) \\ University of Insubria, Italy
}

Doi: 10.19044/esj.2018.c3p3 URL:http://dx.doi.org/10.19044/esj.2018.c3p3

\begin{abstract}
The aim of the paper is to analyze the role of companies as driver of sustainable development and respect for fundamental workers' rights. Trade policies and agreements can have wide-ranging effects on the economy, employment, labour standards, social cohesion, and the environment, including policy development and regulatory aspects. Nowadays the countries are closely tied to one another through trade and investment. This creates a common interest in a well-balanced world economy and properly functioning global system of trade. Thus, the EU wants to ensure that its trade actions are supportive of sustainable development within the EU, in the partner countries, and globally. The sustainability with its economic, social and environmental dimension in all relevant policies is a basic objective set out in the Treaty on the European Union, both as regards the EU's internal policies and external action. Respect for fundamental workers' rights and for environmental protection requirements should be ensured in a context of trade and economic expansion: the jobs created by open trade shall reflect international core labor standards and increased trade flows shall help the rapid spread of green goods, services and technologies around the world. The research presents three case studies on the CSR policy: Nike, Apple and Walmart. These multinationals have been involved in social and environment conflicts. The article researched how companies solved these conflicts and what changes they made in the sustainable policy in relation to those conflicts.
\end{abstract}

Keywords: Sustainable development, sustainable enterprise, workers' rights, scandal 


\section{Introduction, sustainable development, labor and environment provisions}

In modern reality during the international division of labor it's impossible to live on your own. Thus, nowadays the key words are the interdependence of nations and the imperatives that a global system imposes on national economies. The main problem is that majority of states are focused on national interests' strategies caused by country's social-economic needs. However, ignorance of globalization or not adequate recognition of its importance is likely to lead to missing the chance of participation via international relations in globalized economy and gain profits.

Today the European Union (EU) is a "classic model" of successful regional integration, which positively influences the economic development of the member-states as well as neighboring countries. The primary objectives of regional policy are to reduce negative phenomena arising from natural conditions, geographical location or economic processes, and to create, as favorable conditions as possible, for closing the development gap and for encouraging innovative economic activity (Sepashvili, 2015) towards sustainable development.

Sustainable development is the main objective of the international community. It is the way for meeting the needs of present generations without compromising the needs of future generations. It offers a model of progress that reconciles immediate and longer-term needs. Sustainable development brings economic prosperity through and with a high level of environmental protection and social equity and cohesion. The sustainability with its economic, social and environmental dimension in all relevant policies is also an important objective set out in the Treaty on the European Union, both as regards the EU's internal policies and external action (DG trade, online).

EU is pursuing the three ambitious dimensions: sustainable development, labor and environment provisions. Respect for fundamental workers' rights and for environmental protection requirements should be ensured in a context of trade and economic expansion: the jobs created by open trade shall reflect the international labor standards, and increased trade flows shall help the rapid spread of sustainable production of goods, services and to use sustainable technologies around the world.

Free trade agreements need to contain strong provisions to promote the respect of labor rights in every country. The Commission will make it a priority to see that the trading partners implement rules that respect labor standards rights like the abolition of child labor, the rights of workers to organize and non-discrimination at work (Gazzola, 2014). Properly functioning markets and sustainable production chains are important because they encourage local and foreign enterprises and investors to become active in developing countries. The point is to make financing available, to appeal to 
investors, to introduce new techniques, and to pay particular attention to sustainable (people, planet, profit) production processes.

Sustainable enterprises respect for human and workplace rights is engrained in the company culture and guides the interactions with employees, partners, suppliers, customers, consumers, and the communities they serve.

\section{Research methodology}

The research methodology is based on the theoretical analysis of available literature on sustainability frameworks, as well as methodologies for the integration of development models and sustainable development.

This paper adopts a conceptual review approach. A critique of the current literature that supports the different sustainable development practices and their effect on labor rights are carried out. Consequently previous literature provided the qualitative data used in this paper.

Qualitative researches were developed in the social sciences to enable researchers to study social and cultural phenomena. The motivation for doing qualitative research, as opposed to quantitative research, comes from the observation that, if there is one thing, which distinguishes humans from the natural world, it is our ability to talk! Qualitative research methods are designed to help researchers understand people and the social and cultural contexts within which they live. Kaplan and Maxwell (1994) argue that the goal of understanding a phenomenon from the point of view of the participants and its particular social and institutional context is largely lost when textual data are quantified.

The first part is about the literature review. The authors describe and synthesize the literature on the topic of sustainable development because they are very wide and varied. The literature and definitions research was conducted analyzing the lines of thought retrieved in the major and specialized journals. The second part is about role of European Union in support and implement sustainable development and the worker rights. In the paper we show four examples of companies that learn from the scandals about the problems with workers rights. The paper aims to answer the following question: Do social conflicts affect a company's sustainable policy?

\section{Literature review}

The first well known definition of sustainable development was introduced in the Brundtland Commission report in 1987: "Development that meets the needs of the present, without compromising the ability of future generations to meet their own needs." (World Commission on Environment and Development WCED, 1987). Sustainability is based on the idea that resources should as needed for present needs but not be used faster than they can naturally regenerate and be available for future and that the negative 
effects of the processes for production of goods can not be transferred to future generations. Elkington goes more into detail when arguing that companies should not only focus on enhancing its value through maximizing profit and outcome without worrying about the consequences of general environmental but concentrate on environmental and social issues equally (Elkington, 1997). In effect sustainability implies: "... a broad interpretation of ecological economics where environmental and ecological variables and issues are basic but part of a multidimensional perspective. Social, cultural, health-related and monetary/financial aspects have to be integrated into the analysis" (Söderbaum, 2008).

Moreover, referring to the definition by the "Brundtland Commission" (1987), Adams (2006: 1) observes: "Over these decades, the definition of sustainable development evolved. ... This definition was vague, but it cleverly captured two fundamental issues, the problem of the environmental degradation that so commonly accompanies economic growth, and yet the need for such growth to alleviate poverty".

The United Nations Secretary-General, Kofi Annan (2002), challenged business leaders to join an international initiative, the Global Compact, that would bring companies together with UN agencies, labor and civil society to embrace a set of shared values and principles in the areas of human rights and labor and environmental standards.

Costanza and Patten (1995) emphasized, taking the meaning of sustainability from biology, that: "Biologically, sustainability means avoiding extinction and living to survive and reproduce. Economically, it means avoiding major disruptions and collapses, hedging against instabilities and discontinuities. Sustainability, at its base, always concerns temporality, and in particular, longevity".

Nevertheless, in general, as Pearce (1999: 69) has commented: "defining sustainable development is not a difficult issue. The difficult issue is in determining what has to be done to achieve sustainable development, assuming it is a desirable goal"'.

Sustainable development was further developed at the World Environment Conference in Rio de Janeiro in 1992 with Agenda 21 and Local Agenda 21. The Local Agenda 21 concept has since been taken up by an increasing number of cities in countries around the world (2003). In 2012, twenty years after the first Earth Summit the key directions of green economy development and poverty elimination were discussed at the Rio+20. The concept of sustainable development was revised by putting the emphasis on the social and human dimensions that inherently broaden the scope of ecological and economic pillars of sustainable development.

According to the Rio Declaration 1992 and Agenda 21 (2003), any strategy for sustainable development has to include all dimensions of 
economic, social, ecological, spatial and cultural development (World Bank, 2001). Sustainable social development here means continuous progression towards creation of a human society that treats equally all cultural, racial and language differences. Equitable distribution of resources, revenues and information, are other necessities of social justice. "Sustainable Development is a dynamic process which enables all people to realize their potential and improve their quality of life (Gazzola and Querci, 2017) in ways which simultaneously protect and enhance the Earth's life support systems" (Forum for the Future, 2000).

\section{EU Sustainable development and the role of companies:}

The EU interventions operate at three levels.

- At global level: EU is actively involved in the liberalization of goods and services which can deliver environmental benefits; the EU works closely with the International Labor Organization (ILO) to integrate labor considerations into its trade policy and to support the ILO's work.

- At bilateral level: the EU aims for its trade agreements, with both industrialized and developing countries, to include provisions devoted to sustainable development aspects of importance in a trade context. All bilateral trade agreements recently concluded by the EU (e.g. South Korea, Central America, Colombia and Peru, Singapore) contain provisions on Trade and Sustainable Development. These include adherence to key international labor and environment standards and agreements, the prudent use of natural resources such as timber and fish, and the promotion of practices favoring sustainable development such as Corporate Social Responsibility (CSR). The close involvement of civil society is central to the successful implementation of the provisions, Civil Society advisory groups include environment, labor, and business organizations.

- At unilateral level, the EU uses the flagship trade policy instrument: Generalized Scheme of Preferences (GSP), to support sustainable development and good governance in developing countries, granting special tariff rate cuts to developing countries committed to core international agreements on human and labor rights, the environment, and good governance.

Presenting the new proposal, EU Trade Commissioner Cecilia Malmström said:

"Trade is not only a tool to create new economic opportunities for consumers, workers and employers, but also a tool to help the world become a more responsible place. Trade is not just about our economic interests, but also about values. Child labor, insufficient workers' rights or irresponsible corporate behavior are global scourges that I want trade policy to help us deal with. I made it my clear priority in the new 'Trade for All' strategy..." 
The role of enterprises is central for sustainable development. Many of the key priorities and issues of sustainable development are connected with business activities (Robèrt et al., 2002).

Companies use energy and natural resources, consume water, produce waste, emit greenhouse gases, etc. Companies have an influence on all-major global environmental changes and they are made up of people whose decisions influence the production and consumption patterns of others stakeholders: consumers, managers, employees, suppliers, clients, family, community, etc. Companies also affect the environment through industrial accidents.

The United Nation (UN) Global Compact encourages companies to operate responsibly and take strategic actions that support society. It works to ensure that business activity adds value not only to the bottom-line, but also to people, communities and the planet. Companies has to take a comprehensive approach to sustainability incorporating the CSR in the strategy (Gazzola and Colombo, 2014), and lay out some essential elements of corporate sustainability which helps business put into practice: operate responsibly in alignment with universal principles, take strategic actions that support the society around them, push sustainability deep into the corporate identity, companies must commit at the highest level, report annually on their efforts and engage locally where they have a presence.

The other important step is that sustainable companies need to implement sustainable business practices also throughout their supply chain if they want to protect against reputational damage and have positive influences in sustainable development. A company's entire supply chain can make a significant impact in promoting human rights, fair labor practices and environmental progress. Supply chain practices are the biggest challenge to improve the sustainability performance of the companies, but extending the UN Global Compact's Ten Principles into the supply chain can be difficult because of the scale and complexity of many supply chains.

The UN Global Compact encourages companies to make sustainability a priority from the top of the organization. If companies see the supply chain as an extension of their workforce and community, the company can set expectations for best practices across its supply chain. These can include key areas such as selection, training, auditing and remediation (UN Global compact online).

\section{The lessons from Nike, Walmart, Apple and Nestlé:}

In the past numerous scandal involving companies because they didn't ensure a safe and healthy workplace.

The lessons learned from the Nike experience show an example of a multinational corporation that has incorporated CSR into the business strategy. The choice was necessary for its survival. 
By the early 1980s Nike start a strategy of sourcing shoes from lowwage countries in Asia, without worrying about the local sub-contractor. It was the first company who set new rules and regulations about the labor practices all over the world (McHale, Zompetti and Moffitt, 2007). In the early '90s, Nike, like most of its competitors in the industry, did not have a CSR policy and the child labor scandal has been Nike's turning point in building one of the strongest CSR policies in its sector.

In 2000 Nike has been accused of using child labor in the production of its soccer balls in Pakistan. Nike has had to face real questions about its labor practices abroad when it has felt a public-relations impact. Consumers took an immediate action in order to eradicate child labour practices discharged by this company. This can only be done by not buying their products which are produced in the third world and which have suspicion of a child being involved in the process. Nike had to take immediate actions in order to find a solution, otherwise the company's image could be devastated. Nike launched a program, which aimed to monitor the factories in every country where Nike operates, with an increased attention on its practices to be in accordance with the code of conduct. This program also involved investigation of the work conditions worldwide.

Walmart is another company that faced many obstacles over the years. At the end of 2005, the company was accused to use child labor at two factories in Bangladesh for less than \$50 a month making products of the Walmart brand for export to Canada (Cedillo Torres et al., 2012). The 2005 Report on Ethical Sourcing reported that Walmart had ceased to do business with 141 factories, primarily because of underage labor violations. Walmart's 2005 and 2012 COC 'Standard for Suppliers' explicitly establish that Walmart would not tolerate the use of child labor setting the age of 14 as the minimum age for suppliers and subcontractors to hire workers. Walmart's zero tolerance policy for underage workers was changed in 2005.101 If a single underage worker was found in a factory, Walmart ceased business ipso facto. Currently, Walmart publishes a full and complete report on CSR issues called 'Global Responsibility Report' which covers the three dimensions of 'People, Planet, Profit'. This report emphasizes gender equality and a diverse workforce. Walmart has also committed itself to achieving three goals in its Sustainability Report: using $100 \%$ renewable energy, creating zero waste, and selling products that sustain people and the environment.

Also Apple faced the criticism for the practices of an overseas supplier with a bad reputation for workplace safety and fair wages. Apple has been buffeted by attacks in the United States for the workplace conditions and wage rates of its Chinese manufacturer, Foxconn. At the end of 2011 Apple became a participating company in the Fair Labor Association (FLA) and, in doing so, it agreed to abide by the FLA's Workplace Code of Conduct throughout its 
supply chain. The FLA quickly launched a series of independent investigations of Foxconn's factories in Shenzhen and Chengdu, China. Now "Apple's suppliers must live up to this to do business with Apple." They have workplace standards for the entire supply chain. The company continues its efforts to make any number of benefits available to individuals working within its supply chain. By exhibiting a genuine commitment to social responsibility and ethical business practices, corporations like Apple have the power to not only transform their organizations but also their supply chains. Apple is a sustainable company and it isn't limited by the vision of its shareholders and customers.

The next example is a recent problem of Nestlé, the world's largest food producer. The company had problems with the child labor in cocoa supply chain in Côte d'Ivoire and it was sued over allegations that it used child slaves to harvest cocoa. The US Supreme Court has rejected the appeal from Nestlé to dismiss the lawsuit which was left in place by the high court in December 2014, according to Reuters. To deal with the problem, Nestlé tackled child labour in the cocoa supply chain through pioneering monitoring and remediation schemes in Côte d'Ivoire and Ghana, which form part of the Nestlé Cocoa Plan. For the first time, in October 2017, Nestlé published a report laying out the important progress that the company made in tackling child labor. In the Corporate Business Principles and Supplier Code, which guide the behavior of the employees and business partners worldwide, Nestlé strongly oppose any kind of child exploitation, and they're committing to preventing and eliminating it in the supply chain.

\section{Conclusion}

Sustainable enterprises respect for human and workplace rights is engrained in the company culture and guides the interactions with employees, partners, suppliers, customers, consumers, and the communities they serve.

Companies are now almost universally recognized as the primary engine of the economic growth and development needed to alleviate poverty. Business innovation is also needed in meeting sustainable development challenges in the future (Vătămănescu et al., 2017). Multinational corporations are working with small and medium sized suppliers to raise the environmental and social standards of their supply chain. Enterprises that fail to understand these opportunities may soon find themselves overtaken their more responsive competitors or by scandals. From the three examples is clear to understand the role in the sustainable development of the enterprises in the global word. It's also clear that the respect of workers rights is one of the most important goals of the companies. In sustainable enterprises every worker has the right to a fair and safe work environment free of discrimination, where they earn 
competitive wages and can voice their concerns freely, this bring to sustainable development

After the scandals Nike and Apple decided to participate in FLA, the association launched in 1999 by a coalition of industry, labor and non profit advocacy groups, which check the assesses working conditions and monitors attempts to remedy violations in factories, farms and facilities used by its affiliated companies. Walmart has increased the number of audits to control child labor employment.

The four scandals occurred in different time periods. Nestlé has published a report with the progress that the company made in tackling child labor.

In particular, in the early $90 \mathrm{~s}$, the information available to consumers regarding the value chain was very limited. This was the case because there were not many tools that people could use to gather more information; therefore it was very simple to conceal the reality. Later, consumer's awareness become an established concept and when a current or potential buyer has access to the internet and countless sources of information. In the era of internet communication and networks and the increased access to the informations, international organizations, like EU, should focus on promoting enterprise because they become the driver of sustainable growth and decent work, including the enabling environment and the supply chain.

\section{References:}

1. Adams, W. M. The Future of Sustainability: Re-thinking Environment and Development in the Twenty-first Century, 2006, Available at: http://iucn.org

2. Agenda 21. United Nations Department of Economic and Social Affairs. Division for Sustainable Development Agenda 21, 2003. Available http://www.un.org/esa/sustdev/documents/agenda21/english/agenda2 1toc.htm\#pre

3. Annan, K. Strengthening the UN: An Agenda for Further Change. Report. The Secretary General United Nations, September 9, 2002.

4. Brundtland Commission. Our Common Future, Brundtland Report. United Nations World Commission on Environment and Development, 1987.

5. Cedillo Torres, C. A. Garcia-French, M., Hordijk, R., Nguyen, K. and Olup, L., Four Case Studies on Corporate Social Responsibility: Do Conflicts Affect a Company's Corporate Social Responsibility Policy?. Utrecht Law Review, Vol. 8, No. 3, pp. 51-73, 2012, November 2012. Available at SSRN: https://ssrn.com/abstract=2182495Cedillo 
6. Costanza, R. and Patten. B. C. Defining and predicting sustainability. Ecological Economics, 15 (3), 193-196, 1995.

7. DG Trade, Directorate-General for Trade [online]. Available: http://ec.europa.eu/trade/

8. Elkington, J. Cannibals with Forks: Triple Bottom Line of 21st Century Business. Capstone Publishing, Oxford, 1997

9. Forum for the Future, 2000, Annual Report, http://www.forumforthefuture.org.uk

10. Gazzola, P. CSR and the European Integration process: the Italian case, 2nd international scientific conference, International Conference on European Integration 2014, (ICEI 2014), VŠB - Technical University of Ostrava.

11. Gazzola, P. and Colombo, G. CSR integration into the corporate strategy. Cross-Cultural Management Journal, 7(2), 6, 2014.

12. Gazzola, P. and Querci, E. The Connection Between the Quality of Life and Sustainable Ecological Development. European Scientific Journal, ESJ, 13(12), 2017.

13. Kaplan, B and Maxwell, J. A. Evaluating health care information systems: Methods and applications. Qualitative Research Methods for Evaluating Computer Information Systems. JG Anderson, CE Ayden and SJ Jay. Thousand Oaks, Sage, 1994.

14. McHale, J. P., Zompetti, J. P. and Moffitt, M. A. A Hegemonic Model of Crisis Communication Truthfulness and Repercussions for Free Speech in Kasky v. Nike. Journal of Business Communication, 44(4), 374-402, 2007.

15. Pearce, D., Markandya, A. and Barbier, E.B. Blueprint for a green economy. Earthscan, London, 1989.

16. Robèrt, K. H. et al. Strategic sustainable development-selection, design and synergies of applied tools. Journal of cleaner production, 10(3), 197-214, 2002.

17. Sepashvili, E. Integration with the EU: prospects for foreign trade of Eastern partnership countries . Strategica, International Academic Conference, Third Edition, Bucharest, October 29-31, 2015, Local Versus Global, edited by Bratianu, Zbuchea, Pinzaru, Vatamanescu, Leon, SNSPA, Faculty of Management, 6 Povernei Street, Sector 1, Bucharest, Romania, 2015.

18. Söderbaum, P. Understanding sustainability economics: towards pluralism in economics. Earthscan, 2008.

19. UN Global Compact available online: https://www.unglobalcompact.org

20. Vătămănescu, E. M., Gazzola, P., Dincă, V. M., \& Pezzetti, R. Mapping Entrepreneurs' Orientation towards Sustainability in 
Interaction versus Network Marketing Practices. Sustainability, 9(9), $158,2017$.

21. WCED (World Commission on Environment and Development). Our Common Future. Oxford University Press, Oxford, UK, 1987.

22. World Bank. World Development Indicators 2001, The World Bank, Washington, D.C., 2001. 